\title{
An Empirical Investigation of the Trade-Off Theory: Evidence from Jordan
}

\author{
Imad Zeyad Ramadan ${ }^{1}$ \\ ${ }^{1}$ Department of Finance, Applied Science University, Amman, Jordan \\ Correspondence: Imad Zeyad Ramadan, Associate Prof., Department of Finance, Applied Science University, \\ P.O. Box 166, Amman, Jordan. E-mail: i_ramadan@asu.edu.jo
}

Received: January 12, 2015

Accepted: January 23, 2015

Online Published: March 25, 2015

doi:10.5539/ibr.v8n4p19

URL: http://dx.doi.org/10.5539/ibr.v8n4p19

\begin{abstract}
This study aims to test if the Jordanian industrial listed firms follow the trade-off theory in their funding needs strategy during the period 2000-2014. Utilizing data from a sample of the Jordanian industrial firms, the results show that the inverse relationship between profitability and leverage result is not consistent with the trade-off theory, indicating that more profitable Jordanian manufacturing firms tend to issue more equity and less debt to finance their need of funds. The direct relationship result between firms' size and leverage is in line with the trade-off theory, indicating that large firms tend to finance their needs of fund through issuing debt rather than equity. As for the growth leverage relation, the result supports the trade-off theory, but the relation is not statistically significant. In summary, The Jordanian manufacturing firms follow the trade-off theory partially, and the industrial sector have an impact on the financing decision.
\end{abstract}

Keywords: trade-off theory, Jordan

\section{Introduction}

The trade-off theory of capital structure is based on the idea that companies choose between funding through debt or equity by balancing between costs and benefits of each source. The original version of this theory goes back to Kraus and Litzen berger (1973), who took into account the balance between the costs of bankruptcy and the benefits of the tax shield resulting from financing through debt. It is often looked at the trade-off theory as competition to the theory of pecking order theory.

The most important goal of this theory lies in the interpretation of reality that companies finance their needs of money through a combination of debt and equity funds without complete dependence on a single source. Under the theory that there is an advantage of financing through debt which is the tax shield, and there is a cost of financing through debt which is the interest paid and the costs of financial distress of the possibility of bankruptcy of the company. Within this fact, companies seek to reach to the optimal capital structure by balancing between the benefits and the costs of the each source of funds.

This study aims to tests the existence of the trade-off theory in the industrial sector of Amman stock Exchange (ASE) for the period 2000 2014, as it seeks to find if Jordanian industrial listed firms follow trade-off theory in their funding needs strategy during the period 2000-2014.

Thus, the hypothesis that the study seeks to test can be formulated as follows:

H01: Jordanian industrial companies do not follow the trade-off theory in their financing decision.

H02: There is no statistically significant difference between different industrial sectors on relying on debt to finance the companies' need of money.

The rest of the study is prearranged as follows: the second section presents the previous the literature review related to the study, third section presents the data and variables of the study, methodology in the fourth section of the study and the fifth section presents the experimental results and conclusions of the study.

\section{Literature Review}

Prior research on static trade-off theory reached mixed results. On the one hand, study concluded that the optimal capital structure is not significant. Many studies for instance, Titman and Wessels (1988), Rajan and Zingales (1995), and Fama and French (2002) confirmed that the most profitable firms more likely to borrow less. This 
result is not consistent with the trade-off theory expectations that the most profitable firms should borrow more to take advantage of the debt's tax advantage. Graham (2000) found that the profitability firms are financing using debt conservatively. Microsoft Company is the most obvious example of these studies as the company's profitability is considered very high and has a zero-debt policy.

On the other hand, lots of researches were consistent with the trade-off theory and confirm the role of optimal debt ratio (e.g. Hovakimian, Opler, \& Titman, 2001; Korajczyk \& Levy, 2003; Hovakimian, 2004; Hovakimian $\&$ Tehranian, 2004). Frank and Goyal (2004) supported the trade-off theory by investigating relative importance of 39 factors. Welch, 2004 concluded that Firms on their optimal debt ratio do not compensate the effect of stock returns actively, and finds that prior stock returns are the main determinant of market leverage. Flannery and Rangan (2006) disagree with Welch (2004) by finding the impact of firms' prior stock price movements. Often, the companies buy back its shares not to apply a certain financial policy, but rather the desire of the company to approach the optimal debt ratio, (Leary \& Roberts, 2005; Hovakimian, 2006). Strebulaev (2004), and Hennessy and Whited (2004) tried to reconcile the conflicting results of the trade-off theory in a changing framework.

\section{The Data and Variables}

\subsection{Data}

The data that were used in this study are consisted of the existing data in the financial statements of the industrial sample companies, and were extracted from the ASE official website for the time horizon 2000-2014 resulting in 975 firm-year observations.

\subsection{Variables}

\subsubsection{Dependent Variable}

Financial leverage, expressed as the total debt ratio which is the proxy of the trade-off theory, is a ratio used to shed light on firm's way of funding or to compute its capability to meet financial obligations. There are a range of different ratios for this purpose. One of the most commonly and widely used measure of the financial leverage is the ratio of total liability to total assets Beven and Danbolt (2002), Rajan and Zingales (1995) and Booth et al. (2001).

Accordingly, total liability can be defined, proxy of the trade-off theory, as follows:

$$
\text { Leve. }=\frac{\text { total liability }}{\text { total assets }}
$$

Where: Leve. is the financial leverage expressed as the debt ratio a proxy of the trade-off theory. Total liability is the sum of current and long-term liabilities. Total assets are the sum of all types of assets.

\subsubsection{Independent Variables}

\subsubsection{Profitability}

David and Olorunfemi, (2010) tested the effect of Leverage on firm's profitability. Utilizing panel data analysis the study founds a significant direct association between EPS and leverage, and a significant positive relation between DPS and Leverage. This result supports the trade-off theory, as the trade of theory States that the profitable companies better able to meet its debt obligations, and therefore, borrowing costs are relatively lower compared to the least profitable companies, which means that the profitable companies resort to borrow more to take advantage of the tax benefit and the advantage of the relatively low cost. The return on assets will be the proxy of the Profitability and can be defined as follows:

$$
R O A=\frac{\text { net income befor tax }}{\text { total assets }}
$$

Where: ROA is the proxy of the firm's profitability.

\subsubsection{Firm's Size}

Previous studies that examined the relationship between the firm's size and financial leverage concluded that the relationship between them is a statistically significant direct relationship (Bevan \& Danbolt, 2002; Booth et al., 2001; Rajan \& Zingales, 1995; Shah \& Hijazi, 2005). This result support and is in line with the trade-off theory, which suggests that large firms are more profitable than small firms, therefore, they are better able to meet their debt obligations and are less likely to failure to meet commitments. Therefore, large firms get loans at relatively low cost, which encourages them to use debt as a source of funding.

Following Abor (2007), size is measured by the natural logarithm of the total assets, as follows: 


$$
S I Z=\ln (\text { total assets })
$$

Where: $S I Z$ is the natural logarithm of the total assets of the firm, proxy of the firms' size.

\subsubsection{Growth Opportunity}

Myers' (1977) suggested that Firms with high growth opportunities usually do not use long-term liabilities to finance their funding needs to avoid sharing the growth opportunities with debt holders. Accordingly, we expect that there will be an inverse relationship between the growth and long-term debt. But adding the short-term debt to the long-term to get the total debt may alter the direction of the relationship.

Following Zuraidah et al. (2012) and Abor, (2005) growth can be expressed as the sales growth, which is defined as the annual growth rate of the sales as follows:

$$
G R W=\frac{S_{t}-S_{t-1}}{S_{t-1}}
$$

Where: GRW is the annual sales growth proxy of the growth opportunity. $\mathrm{S}$ is the net sales amount. $t^{\text {th }}$ is the time period.

\subsubsection{Industry Effects}

Many studies have concluded that the nature of the industry plays an important role in determining the debt ratio adopted by the company. For example, the utility sector is characterized as high leverage ratios, were high tech sector's characterized by their low leverage ratios.

To control for the industrial sector effect (INS_E), 11 dummy variables, which represent different industries of the Jordanian industrial sector, are used in the econometric model of the study. Sector 1 (Pharmaceutical and Medical Industries), Sector 2 (Chemical Industries), Sector 3 (Paper and Cardboard Industries), Sector 4 (Printing and Packaging), Sector 5 (Food and Beverages), Sector 6 (Tobacco and Cigarettes), Sector 7 (Mining and Extraction Industries), Sector 8 (Engineering and Construction), Sector 9 (Electrical Industries), Sector 10 (Textiles, Leathers and Clothing's), Sector 11 (Glass and Ceramic Industries). The dummy variable takes the value 1 if the firm is in that sector; otherwise it takes the value 0 .

\section{Methodology}

We estimate Equation (1) to test the hypotheses that the trade-off theory is not valid for our sample firms of the industrial sector in the Jordanian capital market. The econometric model of the study to be estimated is as follows:

$$
\text { Leve }_{i t}=\beta_{0}+\beta_{1} R O A_{i t}+\beta_{2} S I Z_{i t}+\beta_{3} G R W_{i t}+\sum_{k=1}^{K} \gamma_{k} D_{i}^{k}+\varepsilon_{i t}
$$

Where: Leve is the financial leverage expressed as the debt ratio a proxy of the trade-off theory. it is the $i^{t h}$ cross sectional firm at the $t^{t h}$ time period. $\beta^{\prime s}$ are the slops of the econometric model to be estimated. ROA is the return on the assets a proxy of the firm's profitability. SIZ is the natural logarithm of the total assets of the firm a proxy of the firms' size. GRW is the annual sales growth a proxy of the growth opportunity. $\sum_{k=1}^{K} \gamma_{k} D_{i}^{k}$ is the industrial sector effect (INS_E). $\mathrm{k}=1,2,3 \ldots 11 . \gamma_{k}$ is the dummy variables coefficients. $\varepsilon$ is the random error. $D$ is the dummy variables for the industry effects takes the value as follows:

$$
D_{k}= \begin{cases}1 & \text { if the } i \text { firm is in the } k \text { sector } \\ 0 & \text { otherwise }\end{cases}
$$

If the results show a statistically significant positive relationship between profitability (ROA) and debt ratio (Leve.) it means that the trade-off theory is valid for the Jordanian industrial firms. Also if at least one of the dummies variables coefficients is significant it will indicate the existence of the industrial effect on the trade-off theory.

\section{Regression Analysis}

Table 1 shows the results of the regression analysis of the equation (1), the table shows a statistically significant inverse relationship between profitability $(\mathrm{ROA})$ and Leverage (coeff $=-0.071$, $\mathrm{p}$-value $=0.019)$. This implies that larger Jordanian industrial firms tend to rely less on debt in their capital structure. This result is consistent with the view that the most profitable companies resort to funding through internal funding and equity funds. This result is consistent with Kinsman and Newman (1998) and Majumdar and Chibber (1999) which concluded that, in general, the least profitable companies have usually higher leverage. This result is not consistent with the trade-off theory which states that the more profitable is the company the higher is the debt ratio. 
Table 1. Regression analysis finding for model (1)

\begin{tabular}{|c|c|c|c|c|}
\hline \multicolumn{2}{|c|}{ Variable } & Coefficient & t-value & p-value \\
\hline \multicolumn{2}{|c|}{ Constant } & $1.057^{* *}$ & 5.245 & $1.011 \mathrm{E}-7$ \\
\hline \multicolumn{2}{|c|}{ ROA } & $-0.071^{*}$ & 2.078 & 0.019 \\
\hline \multicolumn{2}{|c|}{ SIZ } & $0.059^{* *}$ & 3.057 & 0.001 \\
\hline \multicolumn{2}{|c|}{ GRW } & -0.0091 & 1.054 & 0.146 \\
\hline \multicolumn{5}{|c|}{$I N S_{-} D^{(1)}$} \\
\hline & $D_{1}$ & -0.0214 & 1.948 & 0.025 \\
\hline & $D_{5}$ & 1.0248 & 4.364 & $7.160 \mathrm{E}-6$ \\
\hline & $D_{8}$ & -0.0035 & 2.891 & 0.001 \\
\hline \multicolumn{2}{|c|}{ Adjusted R-Square } & 0.364 & & \\
\hline & Regression & 14 & & \\
\hline & Residual & 960 & & \\
\hline & Total & 974 & & \\
\hline & F. & 40.967 & & \\
\hline & Sig. & 0.000 & & \\
\hline
\end{tabular}

Note. Dependent variable: ROA a proxy of the performance, *, **; significant at $0.05,0.01$ level respectively. (1) Only dummy variables for the industrial sector effect with significant effect were reported. Leve is the financial leverage expressed as the debt ratio a proxy of the trade-off theory. ROA is the return on the assets a proxy of the firm's profitability. SIZ is the natural logarithm of the total assets of the firm a proxy of the firms' size. GRW is the annual sales growth a proxy of the growth opportunity. INS_E is the industrial sector effect.

The table also shows a statistically significant direct relationship between the size of the Jordanian industrial firms and Leverage (coeff $=0.059$, $p$-value $=0.001$ ). This result is in line with Titman and Wessels (1988), Rajan and Zingales (1995), Deloof and Verschueren (1998) and Booth et al. (2001). This result is in line with the view that information asymmetries are less for large firms, and thus large firms have easier access to the market of debt finance with lower cost of funding, comparing to smaller firms, accordingly, this leads to higher debt ratio for larger firms. This result is consistent with the trade-off theory.

According to the trade-off theory, an inverse relationship between the growth opportunity and leverage is expected, due to the fact that high growth firms tend to have an overvalued share which encourages managers to issue shares to finance their needs for money, which makes the relationship between growth and leverage is an inverse relationship. The result shown in Table 1 supports the trade-off theory (coeff $=-0.0091, \mathrm{p}$-value $=0.149$ ), but the results were not statistically significant.

For the second null hypothesis, which states that there are no statistically significant differences for the leverage level among various industrial sectors, the result shows that the coefficients for dummy variable 1,5 and 8 were significant, indicating that the type of the industrial sector has a significant impact on the decision of using debt to finance the firms' need of money. Also the results shows that Pharmaceutical and Medical Industries sector and Engineering and Construction sector rely less on the debt than Food and Beverages sector. This result is consistent with the view that the utility sector more dependent on debt than high-tech sectors.

As for the R square, the results shows that profitability, firms' size and the industrial effect explain about $36 \%$ (Adjusted R-Square $=0.364$ ) of the variation in the Jordanian manufacturing firms' leverage.

\section{Conclusion}

Regression analysis has shown conflicting results, the inverse relationship between profitability and leverage result is not consistent with the trade-off theory, indicating that more profitable Jordanian manufacturing firms tend to issue more equity and less debt to finance their need for funds. The direct relationship result between firms' size and leverage is in line with the trade-off theory, indicating that large firms tend to finance their needs of fund through issuing debt rather than equity. As for the growth leverage relation, the result in table 1 supports the trade-off theory, but the relation is not statistically significant.

In summary, The Jordanian manufacturing firms follow the trade-off theory partially, and the industrial sector 
have an impact on the financing decision.

\section{Acknowledgements}

The author is grateful to the Applied Science Private University, Amman, Jordan, for the financial support granted to this research project (Grant No. DRGS-2014-2015-53).

\section{References}

Abor, J. (2007). Corporate governance and financing decisions of Ghanaian listed firms. Corporate Governance: The International Journal of Business in Society, 7(1), 83-89.

Bevan, A., \& Danbolt, J. (2000). Dynamics in the determinants of capital structure in the UK. Capital Structure Dynamics Working Paper No. 2000-9.

Booth, L., Aivazian, V., Demirguc-Kunt, A., \& Maksimovic, V. (2001). Capital structures in developing countries. The Journal of Finance, 56(1), 87-130. http://dx.doi.org/10.1111/0022-1082.00320

David, D. F., \& Olorunfemi, S. (2010). Capital structure and corporate performance in Nigeria petroleum Industry: panel data analysis. Journal of Mathematics and Statistics, 6(2), 168-173. http://dx.doi.org/10.3844/jmssp.2010.168.173. http://dx.doi.org/10.3844/jmssp.2010.168.173

Deloof, M., \& Verschueren, I. (1998). De determinanten van de kapitaalstructuur van Belgische ondernemingen. Tijdschrift voor Economie en Management, 42(2), 165-188.

Fama, E. F., \& French, K. R. (2002). Testing trade-off and pecking order predictions about dividends and debt. Review of Financial Studies, 15(1), 1-33. http://dx.doi.org/10.1093/rfs/15.1.1

Flannery, M. J., \& Rangan, K. P. (2006). Partial adjustment toward target capital structures. Journal of Financial Economics, 79(3), 469-506. http://dx.doi.org/10.1016/j.jfineco.2005.03.004

Frank, M. Z., \& Goyal, V. K. (2007). Trade-off and pecking order theories of debt. Handbook of Corporate Finance: Empirical Corporate Finance, 2, 1-82.

Graham, J. R. (2000). How big are the tax benefits of debt? Journal of Finance, 55, 1901-1941. http://dx.doi.org/10.1111/0022-1082.00277

Hennessy, C., \& Whited, T. (2004). Debt Dynamics. Journal of Finance, 60, 1129-1165. http://dx.doi.org/10.1111/j.1540-6261.2005.00758.x

Hovakimian, A. (2004). The role of target leverage in security issues and repurchases. Journal of Business, 77(4), 1041-1072. http://dx.doi.org/10.1086/422442

Hovakimian, A. (2006). Are observed capital structures determined by equity market timing? Journal of Financial and Quantitative Analysis, 41(1), 221-243. http://dx.doi.org/10.1017/S0022109000002489

Hovakimian, A., Hovakimian, G., \& Tehranian, H. (2004). Determinants of target capital structure: The case of dual debt and equity issues. Journal of Financial Economics, 71(3), 517-540. http://dx.doi.org/10.1016/S0304-405X(03)00181-8

Hovakimian, A., Opler, T., \& Titman, S. (2001). The debt-equity choice. The Journal of Financial and Quantitative Analysis, 36(1), 1-24. http://dx.doi.org/10.2307/2676195

Kinsman, M., \& Newman, J. (1998). Debt tied to lower firm performance: Finding calls for review of rise in debt use. Graziadio Business Review, 1(3).

Korajczyk, R., \& Levy, A. (2003). Capital structure choice: Macroeconomic conditions and financial constraints. Journal of Financial Economics, 68, 75-109. http://dx.doi.org/10.1016/S0304-405X(02)00249-0

Kraus \& Litzenberger, R. H. (1973). A state-preference model of optimal financial leverage. Journal of Finance, 911-922.

Leary, M. T., \& Roberts, M. R. (2005). Do firms rebalance their capital structures? The Journal of Finance, 60(6), 2575-2619. http://dx.doi.org/10.1111/j.1540-6261.2005.00811.x

Majumdar, S. K., \& Chibber, P. (1999). Capital structure and performance: Evidence from a transition economy on an aspect of corporate governance. Public Choice, 98, 287-305. http://dx.doi.org/10.1023/A:1018355127454

Myers, S. C. (1977). Determinants of corporate borrowing. Journal of Financial Economics, 5, 147-175. http://dx.doi.org/10.1016/0304-405X(77)90015-0 
Rajan, R. G., \& Zingales, L. (1995). What do we know about capital structure? Some evidence from $\begin{array}{llll}\text { international data. Journal of } & \text { Finance, } & 50, & 1421-1460 .\end{array}$ http://dx.doi.org/10.1111/j.1540-6261.1995.tb05184.x

Shah, A., \& Hijazi, S. (2005). The determinants of capital structure in Pakistani listed non-financial firms. AGM \& conference of Pak Society of Development Economics.

Strebulaev, I. A. (2004). Do tests of capital structure theory mean what they say? Stanford Working paper.

Titman, S., \& Wessels, R. (1988). The determinants of capital structure choice. The Journal of Finance, 43(1), 1-19. http://dx.doi.org/10.1111/j.1540-6261.1988.tb02585.x

Welch, I. (2004). Capital structure and stock returns. Journal of Political Economy, 112(1), 106-131. http://dx.doi.org/10.1086/379933

Zuraidah, A. et al. (2012). Capital structure effect on firms performance: Focusing on consumers and industrials sectors on Malaysian firms. International Review of Business Research Papers, 8(5), 115-137.

\section{Copyrights}

Copyright for this article is retained by the author(s), with first publication rights granted to the journal.

This is an open-access article distributed under the terms and conditions of the Creative Commons Attribution license (http://creativecommons.org/licenses/by/3.0/). 